\title{
Pengembangan Model Pembelajaran Abad 21 di SD Negeri 126 Borong Kecamatan Herlang Kabupaten Bulukumba
}

\section{Nur Afni ${ }^{1^{*}}$, Abdul Wahid ${ }^{2}$, Sri Hastati ${ }^{3}$, Abrina Maulidnawati Jumrah ${ }^{4}$, Muthmainnah Mursidin 5}

1, 3, 4, PGSD, Universitas Islam Makassar

2, PGSD, STKIP Andi Mattappa

5. Pend. Bahasa Inggris, Universitas Islam Makassar

1'nurafni.dty@uim-makassar.ac.id, ${ }^{2}$ abdulwahidherlang@gmail.com, ${ }^{3}$ hastati18o2@gmail.com,

${ }^{4}$ abrinamaulidnawati.dty@uim-makassar.ac.id, ${ }^{5}$ muthmainnahmursidin.dty@uim-makassar.ac.id

\section{Abstrak}

Kemajuan suatu bangsa sangat ditentukan oleh kualitas sumber daya manusianya. Sementara kualitas sumber daya manusia bergantung pada kualitas pendidikan. Peran pendidikan sangat penting untuk menciptakan masyarakat yang cerdas, damai, terbuka, dan demokratis. Oleh karena itu, tujuan utama dalam kegiatan ini adalah pembaharuan pendidikan harus selalu dilakukan untuk meningkatkan kualitas pendidikan suatu bangsa. Prosedur pelaksanaan dalam penelitian ini adalah sebagai berikut: 1) Perencanaan, 2) Pelaksanaan, 3) Evaluasi. Instrumen yang digunakan dalam PKM ini yaitu: 1) tes, 2) angket/kuesioner, dan 3) dokumentasi. Lokasi dalam PKM ini adalah SD Negeri 126 Borong Kecamatan Helang Kabupaten Bulukumba. Subjeknya adalah guru dan peserta didik di SD Negeri 126 Borong Kecamatan Helang Kabupaten Bulukumba. Hasil temuan dari kegiatan Penerapan model pembelajaran abad 21 yang selama ini diimplementasikan di SD dapat membuat peserta didik mengetahui bahwa pendidikan yang mereka tempuh sangat penting serta bermanfaat dalam menyelesaikan masalah dan situasi di dunia nyata sekarang ini. Melalui pengembangan model pembelajaran abad 21, peserta didik dapat mengatasi situasi dunia nyata. Integrasi subjek model pembelajaran abad 21 akan lebih efektif jika menggunakan pendekatan yang strategis dalam implementasinya sehingga dapat membuat peserta didik belajar lebih relevan, merangsang munculnya pengalaman bermakna, mendorong peserta didik untuk berpikir kritis dan memecahkan masalah serta meningkatkan retensi. Model pembelajaran abad 21 adalah pembelajaran yang bertujuan untuk meningkatkan mutu pendidikan dalam rangka menjawab tantangan, baik tantangan internal dan tantangan eksternal. Pembelajaran abad 21 tidak bermakna hanya penguatan praktis pendidikan dalam bidang-bidang secara terpisah, melainkan mengembangkan pendekatan pendidikan yang mengintegrasikan keempat bidang tersebut, dengan memfokuskan proses pendidikan pada pemecahan masalah dalam kehidupan sehari-hari maupun kehidupan profesi.

Kata Kunci: Pengembangan; Pembelajaran Abad 21 


\section{Pendahuluan}

SD Negeri 126 Borong Kecamatan Herlang Kabupaten Bulukumba merupakan Sekolah Negeri dengan akreditasi sekolah B dengan jumlah guru sebanyak 7 orang, tenaga administrasi sekolah 1 orang, tenaga honor sekolah/operator sekolah 1 orang. Jumlah keseluruhan guru, tenaga administrasi sekolah dan operator sebanyak 9 orang. 6 orang dengan kualifikasi S-1 (Starata satu), dan 1 orang dengan kualifikasi S-2 (Strata dua) yaitu kepala sekolah. Melihat keadaan guru, maka dapat di simpulkan bahwa di sekolah tersebut cukup memadai karena dari 7 orang gurunya telah terdapat 4 (empat) atau $20 \%$ gurunya telah tersertifikasi. Jumlah peserta didik di SD Negeri 126 Borong keseluruhan 49 orang, laki-laki 26 dan perempuan 23 orang. Sarana dan peserta didik juga cukup memadai untuk tingkatan SD di daerah.

Berdasarkan informasi tersebut, maka penulis tertarik untuk melakukan observasi secara langsung ke lokasi mitra di SD Negeri 126 Borong Kecamatan Herlang Kabupaten Bulukumba pada tanggal 15 Desember 2020 dengan mewawancarai kepala sekolah, guru, dan melakukan observasi suasana sekolah dan proses belajar mengajar. Tujuan dan manfaat model pembelajaran abad 21 dalam peradaban pendidikan sejalan dengan tuntutan pendidikan abad ke-21, yaitu agar pendidik dan peserta didik memiliki kecakapan hidup yang lebih bernilai yang ditandai dengan keterampilan beriman dan bertakwa, memiliki karakter sebagai pemikir, cakap dalam pennggunaan teknologi dan informasi, terampil dalam komunikasi interaktif dengan cerdas dan rendah hati, serta mampu mengembangkan perencanaan, memetakan hasil pencapaian, terampil mengerjakan perangkat kerja, dan meningkatkan keterampilan yang sejalan dengan perkembangan teknologi dewasa ini.

\section{Metode Pelaksanaan}

Lokasi dalam PKM ini adalah SD Negeri 126 Borong Kecamatan Helang Kabupaten Bulukumba. Subjeknya adalah guru dan peserta didik di SD Negeri 126 Borong Kecamatan Helang Kabupaten Bulukumba.

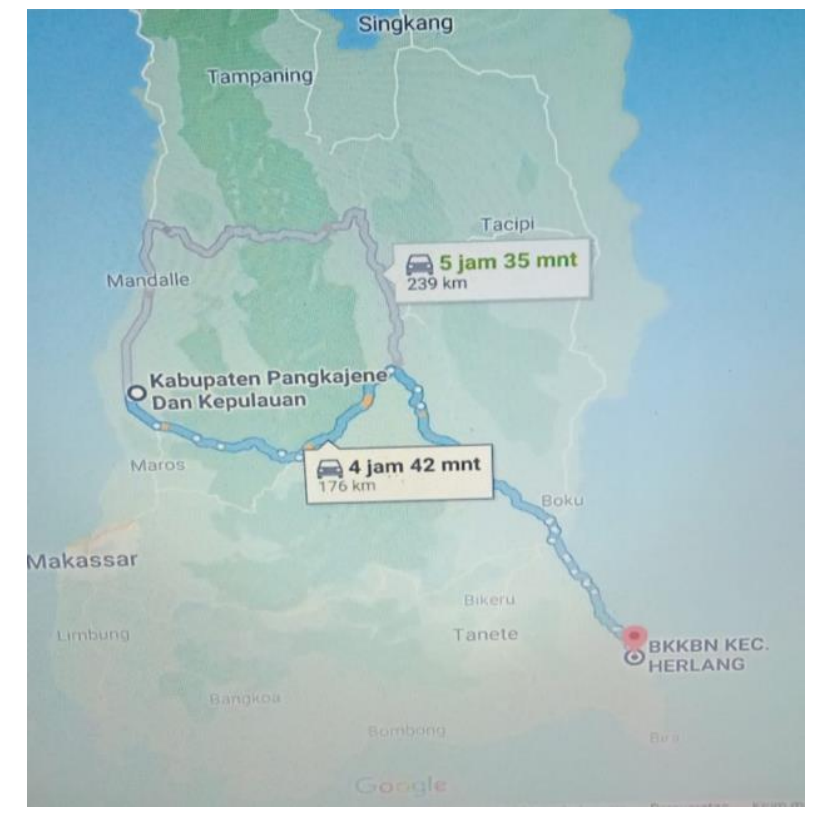

Gambar 1. Peta lokasi kegiatan 
Mitra dalam PKM (Pengabdian Kemitraan Masyarakat) ini adalah SD Negeri 126 Borong Kecamatan Herlang Kabupaten Bulukumba. Berdasarkan orbitasi desa tersebut memiliki ketinggian dari permukaan laut $200 \mathrm{M}$ dan terjauh dengan Ibu kota Kabupaten kurang lebih 42 kilometer. Jarak pusat pemerintahan kecamatan Herlang dengan kabupaten Pangkep Ibukota Provinsi Sul-Sel adalah kurang lebih 176 km yang dapat di tempuh selama 4 jam 42 menit lewat jalan tol, sedangkan tanpa jalan tol menempuh jarak 5 jam 35 menit dalam perjalanan antara kampus STKIP Andi Mattappa dengan mitra (SD Negeri 126 Borong Kecamatan Herlang Kabupaten Bulukumba Provinsi Sulawesi Selatan.

Pelaksanaan PKM ini menggunakan metode pelatihan dan workshop. Adapun rincian kegiatannya adalah sebagai berikut:

1. Workshop pengembangan kurikulum 2013 berorientasi pada model pembelajaran abad 21 yaitu 4 C (Communication, Collaboration, Critical Thinking and Problem Solving dan Creativity and Innovation).

2. Pelatihan penggunaan model pembelajaran abad $214 \mathrm{C}$ (Communication, Collaboration, Critical Thinking and Problem Solving dan Creativity and Innovation)

3. Pelatihan pengembangan indikator dalam pembelajaran abad 21 (4 C Communication, Collaboration, Critical Thinking and Problem Solving dan Creativity and Innovation).

Prosedur pelaksanaan dalam penelitian ini adalah dimulai dari (1) Perencanaan yaitu Berkoordinasi dengan dengan semua anggota tim, Observasi dan Melakukan sosialisasi. (2) Pelaksanaan yaitu Workshop pengembangan kurikulum 2013 berorientasi pada model pembelajaran abad $214 \mathrm{C}$ (Communication, Collaboration, Critical Thinking and Problem Solving dan Creativity and Innovation); Pelatihan penggunaan model pembelajaran abad $214 \mathrm{C}$ (Communication, Collaboration, Critical Thinking and Problem Solving dan Creativity and Innovation); dan Pelatihan pengembangan indikator dalam pembelajaran abad 21 (Communication, Collaboration, Critical Thinking and Problem Solving dan Creativity and Innovation).(3) Evaluasi dilakukan dengan menggunakan tes, angket/kuesioner, dan dokumentasi. Tes dan kuesioner diberikan sebelum berakhir kegiatan, sedangkan dokumentasi dilakukan saat sedang berlangsungnya kegiatan.

\section{Hasil dan Pembahasan}

Pengembangan model pembelajaran abad 21 yang dilaksanakan di SD Negeri 126 Borong Kecamatan Herlang Kabupaten Bulukumba ini, secara garis besar dapat dibagi menjadi tiga bentuk kegiatan utama, yaitu:

1) Workshop pengembangan kurikulum 2013 berorientasi pada model pembelajaran abad 21 ${ }_{4} \mathrm{C}$ (Communication, Collaboration, Critical Thinking and Problem Solving dan Creativity and Innovation).

Workshop pengembangan kurikulum 2013 dalam pembelajaran abad 21 atau pembelajaran ${ }_{4} C$ kegiatan ini dilaksanakan pada tanggal 2-15 Desember 2020 dengan jumlah guru 7 orang yang sangat berguna untuk meningkatkan: (a) Memahami selukbeluk Kurikulum pembelajaran abad 21, (b) Memahami perangkat pembelajaran Kurikulum 2013 abad 21, (c) Mengetahui penggunaan Kurikulum 2013 dalam 
pembelajaran abad 21, (d) Membentuk karakter peserta didik menurut tujuan dan sasaran Kurikulum 2013, dan (e) Mampu menerapkan Kurikulum 2013 dalam pembelajaran abad 21 atau pembelajaran ${ }_{4} C$ di dalam dan luar sekolah. kegiatan workshop ini berbentuk latihan-latihan dan praktek langsung bagaimana proses implementasi atau pelaksanaan kurikulum 2013 dalam pembelajaran abad 21 yang biasa disebut dengan pembelajaran ${ }_{4} C$ yang dilakukan seorang guru dalam proses pembelajarannya di Sekolah Dasar (SD). Oleh karena itu, pengembangan kurikulum menjadi penting dalam menginovasi, memperbaharui, dan mengembangkan kurikulum yang sebelumnya ke arah yang lebih baik lagi. Kurikulum yang ditawarkan adalah "Kurikululum 2013 dalam pembelajaran abad 21 atau dikenal dengan model pembelajaran 4C".

Program pelatihan ini berhasil direncanakan dan terstruktur dengan matang, meliputi tiga faktor yaitu tanggung jawab, desain program, dan evaluasi dan tindak lanjut. Oleh sebab itu, pada akhir kegiatan pelatihan ini peserta diberi tes untuk mengukur pemahaman guru-guru setelah mengikuti workshop ini.

2) Pelatihan penggunaan model pembelajaran abad $214 \mathrm{C}$ (Communication, Collaboration, Critical Thinking and Problem Solving dan Creativity and Innovation)

Pelatihan penggunaan model pembelajaran abad 21 atau pembelajaran ${ }_{4} \mathrm{C}$ ini dilaksanakan pada tanggal 16-30 desember 2020 gunanya untuk memberikan pemahaman dan kemampuan tentang model pembelajaran abad 21. Pembelajaran abad 21 adalah pembelajaran yang bersifat student centered, artinya pembelajaran ini lebih memberikan peluang yang besar kepada peserta didik untuk mengkonstruksi pengetahuan secara mandiri dan dimediasi dengan teman sebaya. Sebagai tenaga profesional, guru dituntut dapat memvalidasi ilmunya, baik melalui belajar sendiri maupun melalui program pembinaan dan pengembangan yang dilembagakan oleh pemerintah atau masyarakat.

Pelatihan penggunaan model pembelajaran abad 21 yang dapat dilakukan melalui kegiatan seminar, pelatihan, dan pendidikan. Pembinaan guru dilakukan dalam kerangka pembinaan profesi dan karier. Pembinaan profesi guru meliputi pembinaan kompetensi pedagogik, kompetensi kepribadian, kompetensi profesional, dan kompetensi sosial. Dengan demikian sangat jelas dipaparkan bahwa profesi guru merupakan sebuah profesi yang hanya dapat dilaksanakan secara efektif dan efisien oleh seseorang yang dipersiapkan dengan matang untuk menguasai kompetensi guru melalui pendidikan dan/atau pelatihan khusus.

3) Pelatihan pengembangan indikator dalam pembelajaran abad $214 C$ (Communication, Collaboration, Critical Thinking and Problem Solving dan Creativity and Innovation).

Pelatihan pengembangan indikator dalam pembelajaran abad $214 \mathrm{C}$ (Communication, Collaboration, Critical Thinking and Problem Solving dan Creativity and Innovation) kegiatan ini dilaksanakan pada tanggal 3-15 januari 2021 gunanya untuk memudahkan peserta didik dalam mencapai kompetensi dasar. Karena tangga-tangga pencapaian yang berupa kata-kata kerja operasional pada indikator akan sangat memudahkan alur 
berfikir peserta didik yang menuju Kompetensi Dasar. Keberhasilan indikator dalam pembelajaran abad 21 mengandung makna ketuntasan dalam belajar dan ketuntasan dalam proses pembelajaran. Artinya belajar tuntas adalah tercapainya kompetensi yang meliputi pengetahuan, keterampilan, sikap, atau nilai yang diwujudkan dalam kebiasaan berpikir dan bertindak. Fungsi ketuntasan belajar adalah memastikan semua peserta didik menguasai kompetensi yang diharapkan dalam suatu materi ajar sebelum pindah kemateri ajar selanjutnya. Patokan ketuntasan belajar mengacu pada standar kompetensi dan kompetensi dasar serta indikator yang terdapat dalam kurikulum. Dengan demikian pemahaman terhadap kriteria keberhasilan belajar, standar kompetensi dan kompetensi dasar serta indikator yang terdapat dalam kurikulum penting dipahami oleh guru.

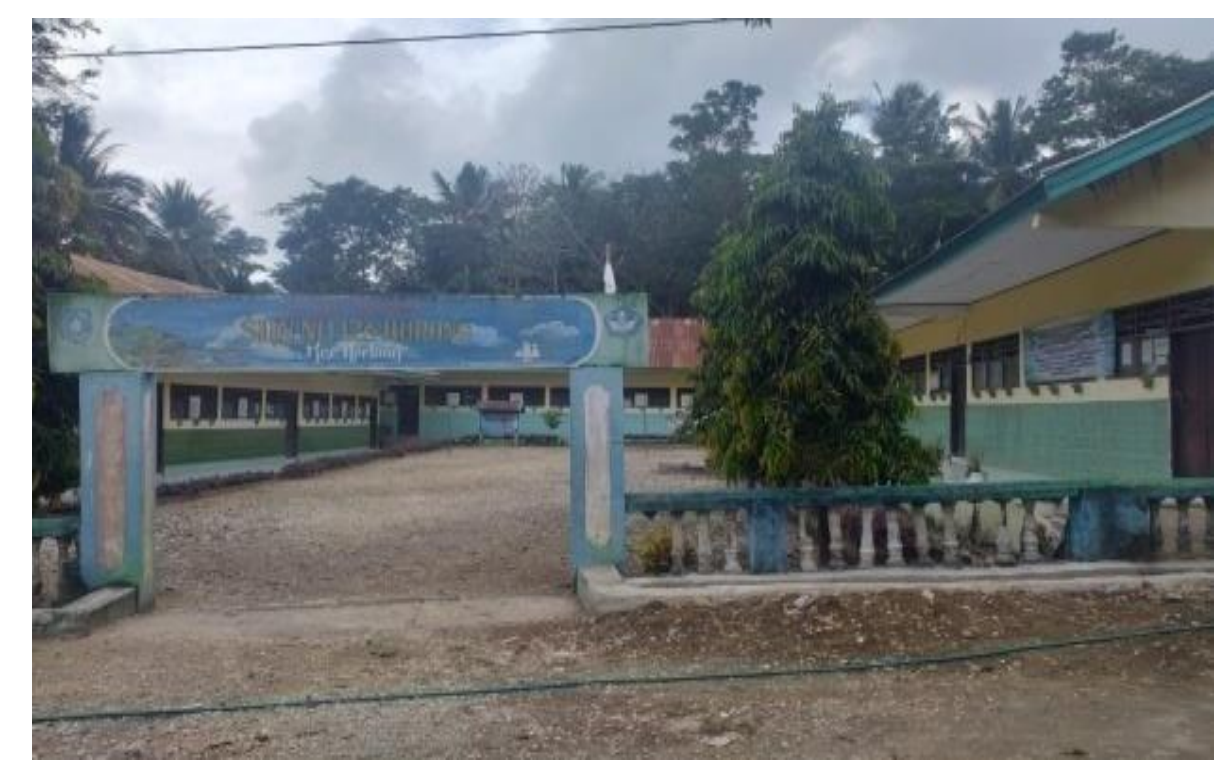

Gambar 2. Tampak depan sekolah lokasi pelaksanaan kegiatan

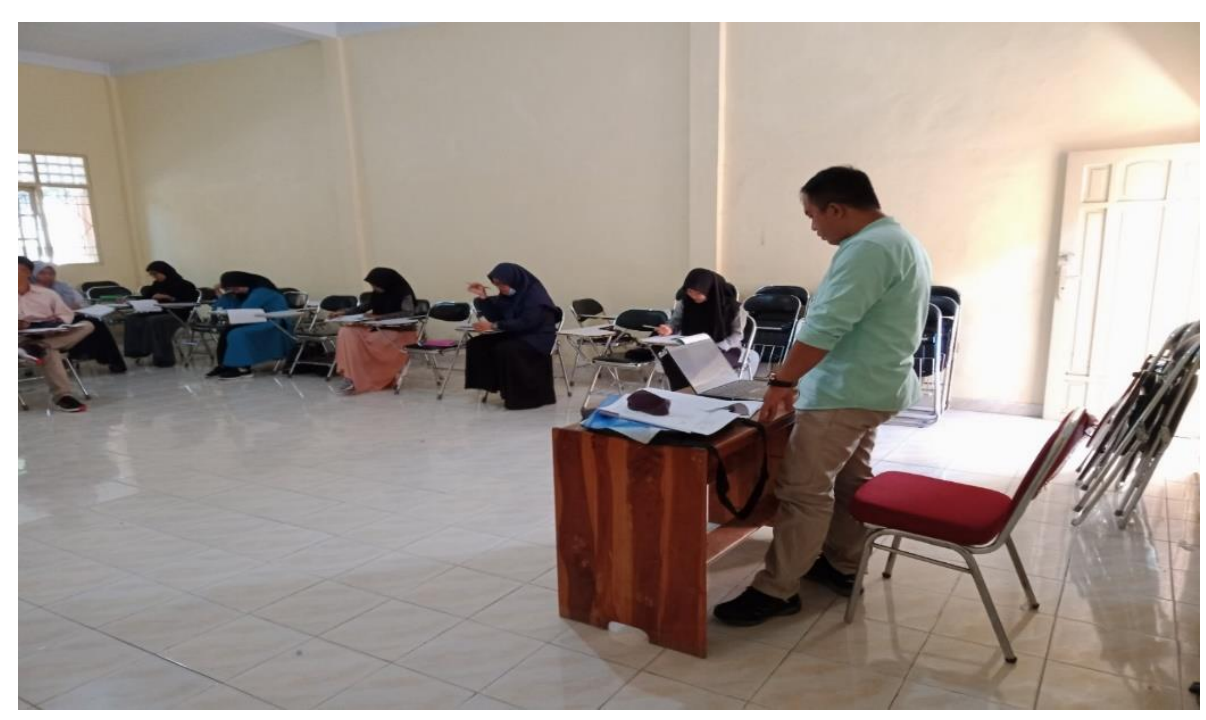

Gambar 3. Suasana kelas saat pelaksanaan kegiatan 


\section{Kesimpulan}

Kesimpulan akhir dari pelaksanaan program pengabdian masyarakat ialah program pelatihan yang produktif akan berhasil jika direncanakan dengan matang, meliputi tiga faktur yaitu tanggung jawab, desain program, evaluasi dan tindak lanjut.

Pembelajaran abad 21 merupakan pembelajaran yang bersifat student centered, artinya pembelajaran yang lebih memberikan peluang yang besar kepada peserta didik untuk mengkonstruksi pengetahuan secara mandiri dan dimediasi dengan teman sebaya. Sebagai tenaga profesional, guru dituntut harus mampu memvalidasi ilmunya, baik melalui belajar sendiri atau otodidak maupun melalui program-program pembinaan dan pengembangan yang dilembagakan oleh pemerintah atau masyarakat.

\section{Ucapan Terimakasih}

Terima kasih kepada FKIP Universitas Islam Makassar dan STKIP Andi Mattappa atas kerjasamanya, Khususnya pada PRODI PGSD yang telah memberikan kesempatan kepada kami untuk mendapatkan bantuan pendanaan kegiatan Pengabdian kepada Masyarakat ini. Terima kasih pula pada mitra kegiatan yaitu SD Negeri 126 Borong Kecamatan Herlang Kabupaten Bulukumba atas kerja samanya dalam kegiatan ini.

\section{Referensi}

Arends, R. I. (2001). Classroom Instruction and Management. New York: MC Grow-Hill Companies, Inc

National STEM Education Center. (2014). Science, Technology, Engineering, and Mathematics (STEM) Education in the US and Its Translational Approaches to Thailand. 30.

Rusman. (2014). Model-Model Pembelajaran Mengembangkan Profesionalisme Guru. Jakarta: Penerbit RajaGrafindo Persada.

Roberts, A. (2012). A Justification for STEM Education. LXXIV, 5.

Snyder, L. G., \& Snyder, M. J. (2008). Teaching Critical Thinking and Problem Solving Skills. 2, 11.

Stohlmann, M., Moore, T., \& Roehrig, G. (2012). Considerations for Teaching Integrated STEM Education. Journal of Pre-College Engineering Education Research, 2(1), 2834. https://doi.org/10.5703/1288284314653

Trianto, M. P. (2009). Mendesain model pembelajaran inovatif-progresif. Jakarta: Kencana. Zubaidah, S. (2018). Mengenal 4C: Learning and innovation skills untuk menghadapi era revolusi industri 4.0. Makalah disampaikan dalam seminar 2nd Science Education National Conference di Universitas Trunojoyo Madura, 1-18. 